\title{
Physical and Chemical Characterization of Fuel Ethanol Coproducts Relevant to Value-Added Uses
}

\author{
R. Bhadra, ${ }^{1}$ K. Muthukumarappan, ${ }^{1}$ and K. A. Rosentrater ${ }^{2,3}$
}

ABSTRACT

Cereal Chem. 87(5):439-447

\begin{abstract}
One of the fastest growing industries in the United States is the fuel ethanol industry. In terms of ethanol production capability, the industry has grown by more than $600 \%$ since the year 2000 . The major coproducts from corn-based ethanol include distillers dried grains with solubles (DDGS) and carbon dioxide. DDGS is used as a livestock feed because it contains high quantities of protein, fiber, amino acids, and other nutrients. The goal of this study was to quantify various chemical and physical properties of DDGS, distillers wet grains (DWG), and distillers dried grain (DDG) from several plants in South Dakota. Chemical properties of the DDGS included crude ash (5.0-21.93\%), neutral detergent fiber (NDF) (26.32-43.50\%), acid detergent fiber (ADF) (10.82-20.05\%), crude fiber (CF) $(8.14-12.82 \%)$, crude protein $(27.4-31.7 \%)$, crude fat (7.4-11.6\%), and total starch (9.19-14.04\%). Physical properties of the
\end{abstract}

DDGS included moisture content $(3.54-8.21 \%), A_{\mathrm{w}}(0.42-0.53)$, bulk density $\left(467.7-509.38 \mathrm{~kg} / \mathrm{m}^{3}\right)$, thermal conductivity $\left(0.05-0.07 \mathrm{~W} / \mathrm{m} \cdot{ }^{\circ} \mathrm{C}\right)$, thermal diffusivity $\left(0.1-0.17 \mathrm{~mm}^{2} / \mathrm{sec}\right)$, color $L^{*}(36.56-50.17), a^{*}(5.2-$ $10.79), b^{*}(12.53-23.36)$, and angle of repose $\left(25.7-47.04^{\circ}\right)$. These properties were also determined for DWG and DDG. We also conducted image analysis and size determination of the DDGS particles. Carbon group characterization in the DDGS and DDG samples were determined using NMR spectroscopy; $O$-alkyl comprised $>50 \%$ of all DDGS samples. Results from this study showed several possibilities for using DDGS in applications other than animal feed. Possibilities include harvesting residual sugars, producing additional ethanol, producing value-added compounds, using as food-grade additives, or even using as inert fillers for biocomposites.
The potential increase in the demand for ethanol as a fuel additive and as a source of alternate fuel has resulted in a radical transformation in agriculture throughout the United States. According to an RFA report, $\approx 15$ billion bushels of corn was produced in 2009 , out of which 4.2 billion bushels of corn went to the ethanol industry for bioethanol production (http://www.ethanolrfa.org). In 2009, 200 manufacturing plants in the United States had a total output production capacity of $\approx 34$ billion L ( 9 billion gal) of ethanol (RFA 2009). Scientists estimated that $>18$ million metric tons of DDGS was produced in 2009. The amount of corn used for the ethanol production and the quantity of coproducts has increased 22-fold during past 20 years.

Industrial processing of ethanol from corn is mainly classified into two types: wet milling and dry milling. Wet milling facilities are generally corporate-owned and have high operating costs. In these, starch is isolated in pure form due to fractionation of the corn kernel into starch, fiber, germ, and protein. Wet milling requires sophisticated equipment, high energy, and water consumption, and yields coproducts such as corn gluten feed (CGF), germ meal, corn gluten meal (CGM), and crude corn oil (Johnson and May 2003).

The other process for obtaining ethanol from corn is dry milling. According to an RFA (2009) report, $85 \%$ production of ethanol comes from dry milling, while only $15 \%$ comes from wet milling. The dry milling process generally does not utilize fractionation (although that is beginning to change), and the primary coproduct is distillers dried grains with solubles (DDGS). DDGS is a dry granular form of the nonfermentable components after corn fermentation in bioethanol processing plants. The dry milling production process usually consists of several unit operations: grinding, cooking, liquefying, saccharifying, fermenting, and distilling the corn grain (Rosentrater 2006). More details about this

\footnotetext{
${ }^{1}$ South Dakota State University, Ag and Biosystems Engineering, Brookings, SD.

${ }^{2}$ Agricultural and Bioprocess Engineer, North Central Agricultural Research Laboratory, USDA-ARS, Brookings, South Dakota. Names are necessary to report factually on available data; however, the USDA neither guarantees nor warrants the standard of the product, and the use of the name by the USDA implies no approval of the product to the exclusion of others that may also be suitable.

${ }^{3}$ Corresponding author. Phone: 605-693-5248. Fax: 605-693-5240. E-mail address: kurt.rosentrater@ars.usda.gov
}

doi:10.1094/CCHEM-02-10-0014

(c) 2010 AACC International, Inc. process are available (Tibelius 1996; Weigel et al 1997; Jaques et al 2003).

After distillation to remove the ethanol, the wet residuals are pressed or spun to remove excess water by centrifugation. Once a portion of the water is removed, the wet cake is mixed with condensed soluble materials and then dried. This final product is DDGS (Rosentrater 2006). The solubles are often referred to as "syrup" in the industry. This coproduct is high in vitamins, fat, and protein but low in fiber. Syrup yields a digestible energy value of $\approx 91 \%$ of that of raw corn (Buchheit 2002 [http://www.siu.edu/ $\sim$ readi/grains/factsheets/historyofethanolproduction.pdf]; Cruz et al 2005). It typically contains $\approx 28-46 \%$ dry matter, $6-21 \%(\mathrm{db})$ fat, $18-22 \%(\mathrm{db})$ protein, and $9-12 \%(\mathrm{db})$ minerals (Schingoethe 2001; Rosentrater and Muthukumarappan 2006).

DDGS is used almost exclusively as livestock feed. Its nutritional components, product shelf-life, transportation, and flowability are vital considerations for overall feed quality. Changes in the final product quality affect the overall cost of DDGS and the economic viability of each ethanol plant. Research has been related to nutritional properties (Spiehs et al 2002), physical properties (Rosentrater 2006), and flowability properties of DDGS (Ganesan et al 2008a,b). DDGS has also been investigated as a protein-rich ingredient for aquafeeds (Chevanan et al 2007, 2008). Additionally, sorption isotherms for varying soluble solid levels and humidity levels were developed; this study observed that modified Halsey and modified exponential models performed well for isotherm data; however, the GMR model followed by a new modified exponential model were the best fit for DDGS (Ganesan et al 2007). Researchers have also worked with using flow agents in DDGS to minimize flow restrictions due to caking of particles (Ganesan et al 2008b).

Thus various studies have been conducted on DDGS yet there are other areas in which DDGS could be used as a value-added product, in addition to its use as animal feed, e.g., removal of fiber from DDGS, biodiesel production from corn oil, biomass gasification, cellulosic degradation of DDGS (Bals et al 2006) for further ethanol production. However, to address these new areas, a complete understanding of physical and chemical properties of DDGS is required. Consequently, the objective of this study was to quantify various physical and chemical properties of DDGS, DWG, and DDG to establish a thorough understanding of these coproducts, which will produce novel uses for these materials. 


\section{MATERIALS AND METHODS}

\section{Sample Collection}

In this study, samples of DDGS and DWG were collected from three commercial fuel ethanol plants (denoted as Plant A, Plant B, and Plant C) in the state of South Dakota. Sampling was done in two batches (Batch I and Batch II) at two different dates; one batch each of DDGS and DWG were collected in September and again in December. The DDGS samples were stored at room temperature $\left(24 \pm 1^{\circ} \mathrm{C}\right)$, while DWG samples were stored under refrigerated conditions $\left(5 \pm 1^{\circ} \mathrm{C}\right)$. DDG was collected from only one plant; one batch was analyzed for the same properties as the DDGS and DWG for comparison purposes.

\section{Experimental Design and Data Analysis}

The samples were subjected to extensive physical and chemical testing. For most properties in a corresponding plant and batch, five replicates were measured. Thus, $n=30$ for each property for each product stream across all plants. For the determinations of crude fat $(\% \mathrm{db})$, crude protein $(\% \mathrm{db})$, and total starch $(\% \mathrm{db})$, however, only two replicates were taken from each plant and the corresponding batches $(n=12)$. Each property was studied using a completely randomized design. For each physical and chemical property, minimum, maximum, mean, and standard deviation values were determined (Microsoft Excel 2003, Redmond, WA). Additionally, a least significant difference (LSD) test was performed for all the physical and chemical properties at a $95 \%$ confidence level using $\alpha=0.05$ (v.9.1, SAS Institute, Cary, NC) to test for differences among the plants. Furthermore, plant-wise comparisons were made for each DDGS and DWG property to quantify variability among the ethanol plants.

\section{Physical Properties}

Moisture content was determined using Approved Method 44-19 in a forced convection laboratory oven (Thelco Precision, Jovan, Winchester, VA) (AACC International 2010). Water activity was measured using a calibrated $A_{\mathrm{w}}$ meter (Sprint TH 500, Novasina, Talstrasse, Switzerland). Thermal properties (conductivity, diffusivity, and resistivity) were determined with a meter (KD2, Decagon Devices, Pullman, WA) that utilized the line heat source probe

TABLE I

Plant-Wise Comparison of DDGS Properties ${ }^{a}$

\begin{tabular}{|c|c|c|c|}
\hline & Plant A & Plant B & Plant C \\
\hline \multicolumn{4}{|l|}{ Physical properties ${ }^{\mathrm{b}}$} \\
\hline Moisture $(\% \mathrm{db})$ & $4.61 \mathrm{a}(1.01)$ & $4.98 \mathrm{a}(1.00)$ & $5.18 \mathrm{a}(1.02)$ \\
\hline Water activity & $0.47 \mathrm{~b}(0.05)$ & $0.45 b(0.05)$ & $0.52 \mathrm{a}(0.04)$ \\
\hline Angle of repose $\left(^{\circ}\right)$ & $38.78 \mathrm{a}(10.23)$ & $36.55 \mathrm{a}(10.56)$ & $24.55 b(9.23)$ \\
\hline Energy content $(\mathrm{MJ} / \mathrm{kg}, \mathrm{db})$ & $19.24 b(0.5)$ & $20.86 a(1.52)$ & 21.09a (1.23) \\
\hline Thermal conductivity $\left(\mathrm{W} / \mathrm{m}{ }^{\circ} \mathrm{C}\right)$ & $0.07 \mathrm{a}(0.00)$ & $0.12 \mathrm{a}(0.01)$ & $0.06 \mathrm{a}(0.05)$ \\
\hline Thermal diffusivity $\left(\mathrm{mm}^{2} / \mathrm{sec}\right)$ & $0.14 \mathrm{a}(0.1)$ & $0.14 \mathrm{a}(0.14)$ & $0.15 \mathrm{a}(0.12)$ \\
\hline Color $b$ & $19.70 \mathrm{a}(2.95)$ & $18.23 \mathrm{a}(2.45)$ & $17.43 \mathrm{a}(2.56)$ \\
\hline \multicolumn{4}{|l|}{ Chemical properties } \\
\hline Crude protein $(\% \mathrm{db})^{\mathrm{c}}$ & $28.33 b(1.25)$ & $30.65 \mathrm{a}(1.20)$ & $29.70 \mathrm{ab}(1.32)$ \\
\hline Crude fat $(\% \mathrm{db})^{\mathrm{c}}$ & $10.76 \mathrm{a}(10.0)$ & $9.75 \mathrm{a}(1.05)$ & $10.98 \mathrm{a}(0.95)$ \\
\hline Crude fiber $(\% \mathrm{db})$ & $9.93 \mathrm{a}(1.45)$ & $10.30 \mathrm{a}(1.23)$ & $10.32 \mathrm{a}(1.53)$ \\
\hline $\operatorname{NDF}(\% \mathrm{db})$ & $31.84 \mathrm{~b}(4.02)$ & $39.90 \mathrm{a}(3.95)$ & $38.46 \mathrm{a}(4.01)$ \\
\hline $\mathrm{ADF}(\% \mathrm{db})$ & $15.56 \mathrm{a}(4.02)$ & $15.21 \mathrm{a}(3.95)$ & $17.89 \mathrm{a}(4.56)$ \\
\hline
\end{tabular}

a Values followed by the same letter are not significantly different $(P<0.05)$. Values in parentheses indicate \pm 1 SD.

${ }^{\mathrm{b}}$ Each property ( $n=30$ samples) based on 5 replicates analyzed from 3 plants collected in 2 batches.

${ }^{\mathrm{c}}$ Each property ( $n=12$ samples) based on 2 replicates analyzed from 3 plants collected in 2 batches.

TABLE II

Plant-Wise Comparison of DWG Properties ${ }^{\mathrm{a}}$

\begin{tabular}{|c|c|c|c|}
\hline & Plant A & Plant B & Plant C \\
\hline \multicolumn{4}{|l|}{ Physical Properties ${ }^{b}$} \\
\hline Moisture (\% db) & $33.17 b(4.23)$ & $29.36 c(3.25)$ & $40.10 \mathrm{a}(5.01)$ \\
\hline Water activity & $0.97 \mathrm{a}(0.01)$ & $0.95 b(0.03)$ & $0.98 \mathrm{a}(0.02)$ \\
\hline Bulk density $\left(\mathrm{kg} / \mathrm{m}^{3}\right)$ & $939.20 b(110.56)$ & $951.93 b(112.36)$ & $1076.16 \mathrm{a}(123.56)$ \\
\hline Thermal conductivity $\left(\mathrm{W} / \mathrm{m}^{\circ} \mathrm{C}\right)$ & $0.12 \mathrm{a}(0.04)$ & $0.13 \mathrm{a}(0.03)$ & $0.14 \mathrm{a}(0.06)$ \\
\hline Thermal diffusivity $\left(\mathrm{mm}^{2} / \mathrm{sec}\right)$ & $0.11 \mathrm{a}(0.02)$ & $0.11 \mathrm{a}(0.04)$ & $0.12 \mathrm{a}(0.03)$ \\
\hline Color $L$ & $57.46 \mathrm{a}(4.12)$ & $46.81 \mathrm{c}(4.23)$ & $54.66 \mathrm{~b}(4.56)$ \\
\hline Color $a$ & $6.56 \mathrm{~b}(1.12)$ & $8.10 \mathrm{a}(1.56)$ & $5.97 \mathrm{~b}(1.03)$ \\
\hline Color $b$ & $25.25 \mathrm{a}(2.1)$ & $22.23 b(1.95)$ & $23.57 \mathrm{ab}(1.56)$ \\
\hline \multicolumn{4}{|l|}{ Chemical properties } \\
\hline Crude protein $(\% \mathrm{db})^{\mathrm{c}}$ & $29.85 \mathrm{a}(1.20)$ & $27.13 b(1.02)$ & $28.83 \mathrm{a}(1.0)$ \\
\hline Crude fat $(\% \mathrm{db})^{\mathrm{c}}$ & $9.70 \mathrm{c}(1.00)$ & $10.93 \mathrm{a}(1.23)$ & $12.75 b(1.56)$ \\
\hline Crude fiber $(\% \mathrm{db})$ & $12.23 \mathrm{a}(1.53)$ & $12.00 \mathrm{a}(1.23)$ & $11.91 \mathrm{a}(1.56)$ \\
\hline $\mathrm{NDF}(\% \mathrm{db})$ & $29.93 c(4.12)$ & $37.17 \mathrm{a}(4.13)$ & $34.61 b(4.56)$ \\
\hline $\mathrm{ADF}(\% \mathrm{db})$ & $13.59 \mathrm{a}(3.95)$ & $14.16 \mathrm{a}(3.68)$ & $14.61 \mathrm{a}(3.56)$ \\
\hline Total starch $(\% \mathrm{db})^{\mathrm{c}}$ & $11.98 \mathrm{a}(1.53)$ & $10.91 \mathrm{a}(1.77)$ & $10.86 \mathrm{a}(1.23)$ \\
\hline $\operatorname{Ash}(\% \mathrm{db})$ & $13.92 \mathrm{a}(3.10)$ & $13.45 \mathrm{a}(2.58)$ & $12.56 \mathrm{a}(1.56)$ \\
\hline
\end{tabular}

a Values followed by the same letter are not significantly different $(P<0.05)$. Values in parentheses indicate \pm 1 SD.

${ }^{\mathrm{b}}$ Each property ( $n=30$ samples) based on 5 replicates analyzed from 3 plants collected in 2 batches.

${ }^{c}$ Each property ( $n=12$ samples) based on 2 replicates analyzed from 3 plants collected in 2 batches. 
technique (Baghe-Khandan et al 1981). Bulk density was measured using a standard bushel tester (Seedburo Equipment, Chicago, IL) as described by the USDA (1999). Color was measured using a spectrophotocolorimeter (LabScan XE, Hunter Associates Laboratory, Reston, VA) using the $L, a, b$ opposable color scales (Hunter Associates). Angle of repose for DDGS and DDG were determined as described by Mohsenin (1980), where the DDGS and DDG were allowed to fall onto a 44-mm diameter circular plate. Gross energy content of DDGS and DDG samples were measured using a bomb calorimeter (1260 Isoperibolic, Parr Instrument, Moline, IL). For all these properties, five replicates were measured.

Particle size distribution was determined using a Rotap sieve analyzer (model RX-29, Tyler Manufacturing, Mentor, OH) for DDGS and DDG, using three replicates, and the geometric mean diameter and geometric standard deviation for each observation was calculated using Standard Method S319.3 (ASAE 2004).

For the DDGS samples only, microscopic analysis was done for the particles from each sieving screen using an Olympus SZH10 stereomicroscope with a DP digital camera (Leeds Instruments, Minneapolis, $\mathrm{MN}$ ), followed by image analysis of the particles by Image ProPlus (software version 4.0, Media Cybernetics, Bethesda, $\mathrm{MD})$ to determine the maximum diameter, minimum diameter, area, and roundness using two replicates for each screen from each sample (Fig. 1).

\section{Chemical Properties}

Ash content was determined using Approved Method 08-01 (AACC International 2010). Acid detergent fiber (ADF), neutral detergent fiber (NDF), and crude fiber analysis was done with a fiber analyzer (model 200, Ankom Technology, Macedon, NY). For these properties, five replicates for each sample were used.

Protein content was determined using Official Method 990.03 and fat content using Official Method 920.39 (AOAC 2000). Total starch was measured as in Xiong et al (1990), and glucose content was measured using a biochemistry analyzer with sensor membrane (2700, YSI, Yellow Springs, OH) following a method adapted from Knudsen (1997). Each of these properties were determined using two replicates only.

Nuclear magnetic resonance (NMR) spectroscopy was conducted at South Dakota State University, Department of Chemistry and Biochemistry. NMR spectra were only done for DDGS (all batches) and DDG (Batch I only) using a single replicate for each sample.

\section{RESULTS AND DISCUSSION}

\section{Plantwise Comparisons}

Ethanol coproducts have been reported to exhibit considerable variability among plants (Rosentrater 2006, 2007). This held true for the samples in this study as well, as evidenced by plantwise comparisons for each DDGS and DWG property. The LSD test (Fisher 1948) at a 95\% significance level $(\alpha=0.05)$ very clearly revealed that there were significant differences for most of the properties among the plants (Tables I and II), as well as within the batches of the same plant (not shown), for both DDGS and DWG. Differences in the physical and chemical properties can be due to variations in the corn cultivar, in the processing conditions, or in the simultaneous effect of these two factors. Previously, variations were found mainly in the DDGS rather than in raw corn cultivars (Belyea et al 2004) and statistical correlation showed little relationship between chemical composition of the corn and the DDGS. It appears that differences arise mostly due to variations in processing parameters associated with DDGS and DWG production. For example, variation in DDGS can occur in the drying step, where DWG and solubles (CDS) are mixed. For our samples, we found variation in the DWG samples (plantwise as well as batchwise). This could be due to variation in the overall fermentation process, fermentation time, enzyme addition, centrifugation, drying, starch degradation time, or other parameters that may vary from plant to plant as well as within a plant over time. All these factors could result in the variations observed among the DDGS and DWG samples obtained from the three different plants.

Because DDGS is sold as livestock feed, variations in the product will affect potential market value (Rosentrater 2007). Moreover, if DDGS is converted into a value-added material, it is even more important to have a consistent product, both in terms of chemical composition and physical properties. Furthermore, physical properties are important for transportation and handling of the coproducts.

\section{DDGS Physical Properties}

Overall physical properties of DDGS are shown in Table III. The moisture content ranged from $3.54 \% \mathrm{db}$ (minimum) to $8.21 \% \mathrm{db}$ (maximum), with a mean value of $5.07 \% \mathrm{db}$. This low moisture content indicates that the DDGS was dried well (for higher shelflife and better flowability) before it was sold in the feed market. This value differed somewhat from moisture content data obtained
$2.38 \mathrm{~mm}$ *

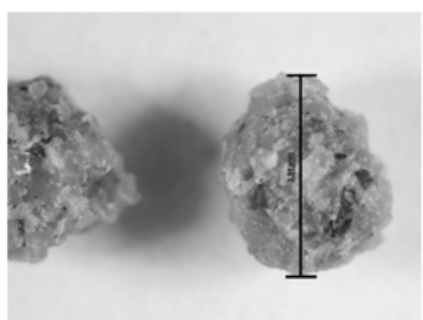

Scale bar $=3.91 \mathrm{~mm}$

$0.595 \mathrm{~mm}$ *

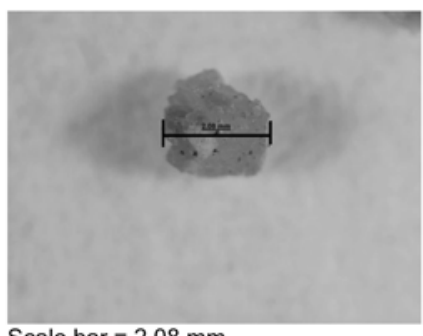

Scale bar $=2.08 \mathrm{~mm}$
$1.68 \mathrm{~mm}$ *

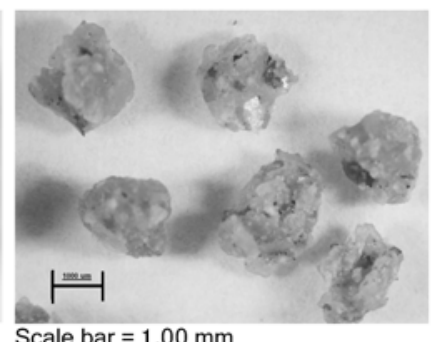

Scale bar $=1.00 \mathrm{~mm}$

$0.420 \mathrm{~mm}$ *

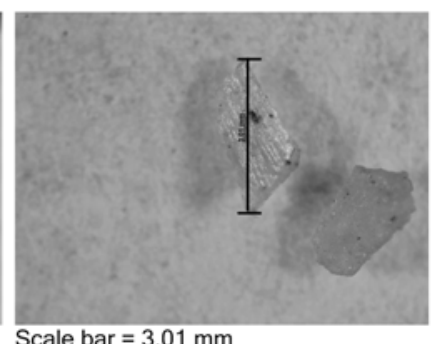

Scale bar $=3.01 \mathrm{~mm}$
$1.19 \mathrm{~mm}$ *

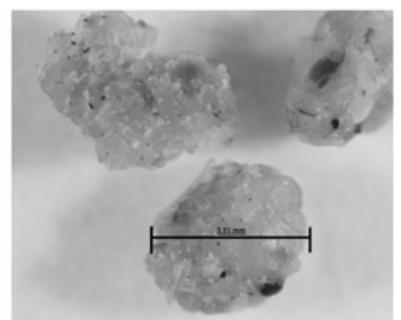

Scale bar $=3.10 \mathrm{~mm}$

$0.297 \mathrm{~mm}$ *

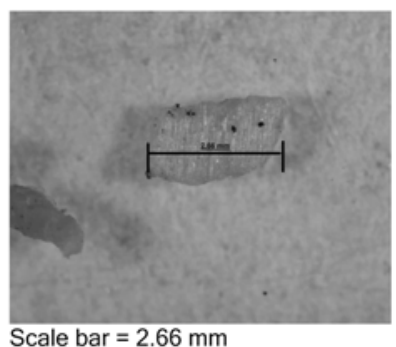

Scale bar $=2.66 \mathrm{~mm}$
$0.841 \mathrm{~mm}$ *

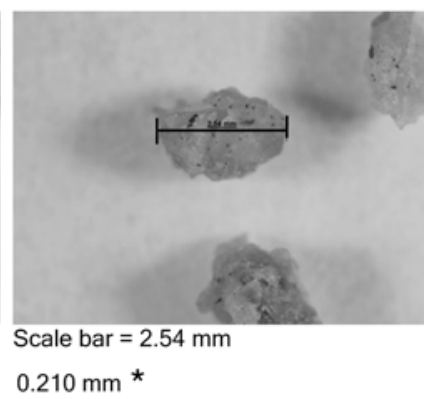

$0.210 \mathrm{~mm}$ *

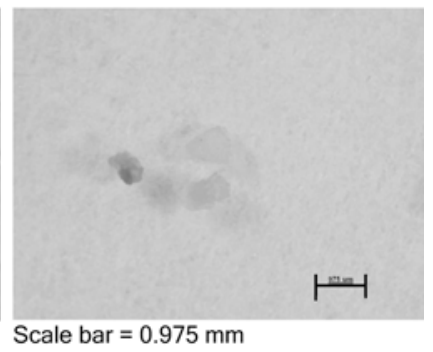

Fig. 1. Microscopic images of DDGS (samples from plant A only) illustrate varying size and shape of DDGS particles. * Sieve opening size (mm). 
by Rosentrater (2006) (mean value $14.7 \% \mathrm{db}$ ), which was higher than our findings. Standard deviation was $<1.21 \%$ as well. Typically, moisture contents of $<12 \%$ are recommended for storage, handling, and transportation of feed products. All DDGS in this study had moisture contents below this threshold. This should help with long-term storage and future value-added applications. Moisture content and soluble levels will affect the flowability of DDGS as well (Ganesan et al 2008a).

DDGS $A_{\mathrm{w}}$ was $0.42-0.53$, with a very low standard deviation of 0.04 . The average $A_{\mathrm{w}}$ was 0.48 . This value differed slightly from earlier results (Rosentrater 2005). The $A_{w}$ is defined as the vapor pressure of water in a biological system divided by that of pure water at the same temperature. It represents the amount of free water available for microbial activity; the lower the $A_{\mathrm{w}}$ value, the less prone the product will be to microbial spoilage. Very low levels of $A_{\mathrm{w}}$ prevent microbial spoilage and increase the shelf-life of the material, which have less chance of bacterial, fungal, and yeast growth at $A_{\mathrm{w}}<0.7$ (Barbosa-Canovas and Vega-Mercado 1996).

Bulk density was $467.7-509.4 \mathrm{~kg} / \mathrm{m}^{3}$, with a mean value of $488.9 \mathrm{~kg} / \mathrm{m}^{3}$. It had a standard deviation of 14.96. Although this variability appeared somewhat high compared to the other physical properties, by considering this in relation to the bulk density mean value, the resulting coefficient of variation was actually relatively low $(3.1 \%)$. The standard deviation was less than that reported by Rosentrater (2006). Bulk density dictates the effective storage capacity for bins and silos; it includes both the material volume as well as the enclosed air spaces between particles. Bulk density reported here is also known as the loose bulk density. But a measure of bulk density with an applied external perturbation is called the tapped bulk density and gives a closer representation of the behavior of the material in an industrial scenario.

The angle of repose was $25.7-47.0^{\circ}$ with an average value of $45.1^{\circ}$. The mean value was very close to that in Rosentrater (2006). However, the range of values in this current study was broader than the data obtained by Rosentrater (2006). This indicates higher variability among the plants and the batches in this study. Finer particles were obtained in our findings, which could affect the flowability of DDGS and may increase the possibility of caking (Ganesan et al 2008b). Angle of repose indicates grain structure: the higher the angle of repose, the lower the potential flow rate because the angle of friction between the particles is greater. Differences among angle of repose values are dependent on the milling parameters and other processing steps used by an individual plant, and it may differ substantially from one plant to another.

The energy content of DDGS was 20.97-21.25 MJ/kg. This range of energy content was very close to that in Morey et al (2006). Thus, it appears that DDGS may prove useful as a feedstock for conversion by gasification or other thermochemical processes. In fact, DDGS could be used to provide energy to the bioethanol process itself (Morey et al 2006). The energy content of corn stover is less than that of DDGS. But a combination of DDGS and corn stover could provide a balanced approach to generate electricity and would be economically feasible (Morey et al 2006). On the other hand, because DDGS is used extensively as livestock feed, this diversion would reduce the amount of feed available (Morey et al 2006).

Thermal conductivity was $0.05-0.07 \mathrm{~W} / \mathrm{m} \cdot{ }^{\circ} \mathrm{C}$, with small variations (standard deviation of 0.01 ), while and thermal diffusivity was $0.1-0.17 \mathrm{~mm}^{2} / \mathrm{sec}$ (with a low standard deviation of 0.01 ). These values were very close to the results of Rosentrater (2006). Thermal properties are inherent to the material and thus less prone to variations among the plants or between batches.

For color parameters, Hunter $L$ value was 36.6-50.2 (mean value of 42.3); Hunter $a$ value was 5.2-10.8 (mean value of 9.65); and Hunter $b$ was 12.5-23.4 (mean value of 20.62). Differences in the ranges of the three color scales were compared to those found by Rosentrater (2006). In this study, we obtained a wide range of color values. This indicates much variation among the batches, as well as between the processing plants. Color values may possibly be related to the nutritional characteristics of the samples (Goihl 1993; Ergul et al 2003), although this has to be established definitively. Rosentrater (2006) found correlations between Hunter color

TABLE III

Overall Physical and Chemical Properties of DDGS

\begin{tabular}{|c|c|c|c|c|}
\hline & Minimum & Maximum & Mean & Standard Deviation \\
\hline \multicolumn{5}{|c|}{ Physical properties ( $n=30$ for each property) ${ }^{\mathrm{a}}$} \\
\hline Moisture (\% db) & 3.54 & 8.21 & 5.07 & 1.21 \\
\hline Water activity & 0.42 & 0.53 & 0.48 & 0.04 \\
\hline Bulk density $\left(\mathrm{kg} / \mathrm{m}^{3}\right)$ & 467.7 & 509.38 & 488.97 & 14.96 \\
\hline Angle of repose $\left(^{\circ}\right)$ & 25.7 & 47.04 & 45.14 & 11.37 \\
\hline Energy content $(\mathrm{MJ} / \mathrm{kg}, \mathrm{db})$ & 20.97 & 21.25 & 21.20 & 0.12 \\
\hline Thermal conductivity $\left(\mathrm{W} / \mathrm{m}^{\circ} \mathrm{C}\right)$ & 0.05 & 0.07 & 0.06 & 0.01 \\
\hline Thermal diffusivity $\left(\mathrm{mm}^{2} / \mathrm{sec}\right)$ & 0.1 & 0.17 & 0.17 & 0.01 \\
\hline Color $L$ & 36.56 & 50.17 & 42.3 & 2.99 \\
\hline Color $a$ & 5.2 & 10.79 & 9.65 & 1.23 \\
\hline Color $b$ & 12.53 & 23.36 & 20.62 & 2.93 \\
\hline \multicolumn{5}{|c|}{ Chemical properties ( $n=30$ for each property $)^{\mathrm{a}}$} \\
\hline Crude ash (\% db) & 5.00 & 21.93 & 12.82 & 3.19 \\
\hline $\operatorname{NDF}(\% \mathrm{db})$ & 26.32 & 43.50 & 36.74 & 4.46 \\
\hline $\operatorname{ADF}(\% \mathrm{db})$ & 10.82 & 20.05 & 16.2 & 4.22 \\
\hline Crude fiber $(\% \mathrm{db})$ & 8.14 & 12.82 & 10.22 & 1.63 \\
\hline Crude protein $(\% \mathrm{db})^{\mathrm{b}}$ & 27.4 & 31.7 & 29.93 & 1.30 \\
\hline Crude fat $(\% \mathrm{db})^{\mathrm{b}}$ & 7.4 & 11.6 & 10.5 & 1.08 \\
\hline Total starch $(\% \mathrm{db})^{\mathrm{b}}$ & 9.19 & 14.04 & 11.07 & 1.77 \\
\hline Glucose $(\% \mathrm{db})^{\mathrm{b}}$ & 0.34 & 2.34 & 0.84 & 0.76 \\
\hline \multicolumn{5}{|l|}{ Carbon partitioning $(\%)^{\mathrm{c}}$} \\
\hline Alkyl (0-50 ppm) & 26.62 & 30.89 & 28.86 & 1.96 \\
\hline$O$-Alkyl (50-100 ppm) & 50.26 & 54.59 & 52.81 & 1.66 \\
\hline Aromatic (100-160 ppm) & 9.64 & 12.35 & 10.75 & 1.07 \\
\hline Carboxyl (160-190 ppm) & 6.99 & 8.24 & 7.56 & 0.44 \\
\hline Carbonyl (190-220 ppm) & 0.05 & 0.15 & 0.11 & 0.04 \\
\hline
\end{tabular}

${ }^{a}$ Each property ( $n=30$ sample), based on 5 replicates analyzed from 3 plants collected in 2 batches.

b Each property $(n=12$ sample), based on 2 replicates analyzed from 3 plants collected in 2 batches.

c Each property ( $n=6$ sample), based on 1 replicate analyzed from 3 plants collected in 2 batches. 
parameters and other physical properties. For example, Hunter $a$ and $b$ values had high correlations with $A_{\mathrm{w}}$ and moderate correlations with thermal properties.

Physical properties of the DDGS are related to flow properties. Particle shapes, sizes, edges, moisture content, angle of repose (and thus frictional characteristics), and bulk density are some key parameters that influence flow and transportation behavior. Caking and stickiness are a common problem for the transportation and logistics of DDGS (Ganesan et al 2008b). Caking is an added burden for the DDGS market, where additional cost is necessary for breaking the consolidated particles. Not only do physical properties play a role, chemical properties are also important to the flowability of DDGS, as well as future and value-added opportunities.

\section{DDGS Chemical Properties}

The results for chemical properties are shown in Table III. The greatest constituent was NDF (with a mean value of $36.74 \% \mathrm{db}$ ), then crude protein (mean of $29.93 \% \mathrm{db}$ ) followed by ADF (mean value of $16.2 \% \mathrm{db}$ ), crude ash (mean of $12.82 \% \mathrm{db}$ ), total starch (mean value $11.07 \% \mathrm{db}$ ), total fat (mean of $10.5 \% \mathrm{db}$ ), crude fiber (mean of $10.22 \% \mathrm{db}$ ), and then glucose (mean of $0.84 \% \mathrm{db}$ ).

Crude ash was $5.0-21.93 \%(\mathrm{db})$. The average ash content was higher compared to the results obtained of Spiehs et al (2002), and our results showed a broader range of ash content. This indicates variations in the amount of minerals among the processing plants where our samples were collected. Because the plants were located at different places, variation among the corn types, which in turn depends on the soil properties and mineral availability, could be one possible reason for the broad range of ash content. However, it has been reported that the ratios of the DWG used and CDS added to during processing, as well as fermentation processes will influence the nutritional properties more than soil behavior and fertility (Spiehs et al 2002). NDF range was 26.32$43.50 \% \mathrm{db}$. ADF range was $10.82-20.05 \% \mathrm{db}$. The crude fiber (CF) was $8.14-12.82 \% \mathrm{db}$. NDF and crude fiber content values are slightly higher than those found by Spiehs et al (2002). ADF values were very similar, however. NDF is the sum of the ADF and the hemicellulose content, whereas ADF is the sum of cellulose and lignin. This category of fibers (NDF, ADF, and CF) is generally called insoluble fiber content. Crude fiber can be determined by subtracting the ADF value from the NDF content. This subtraction is not completely accurate, but a value close to crude fiber is reached (Test Diet 2006, Fiber. Available online at: http:// www.testdiet.com/Fiber.htm). Compared to Speihs et al (2002), it is evident that our samples showed a higher amount of hemicellulose because they showed higher NDF and CF contents, but similar ADF contents. The difference of NDF value from the ADF indicates the presence of higher amount of hemicellulose content in the DDGS. Our results also indicated a higher average NDF value than the protein content $(29.93 \% \mathrm{db})$, which means our DDGS samples were higher in overall cellulose, lignin, and hemicellulose.

These results suggest that DDGS could possibly be a viable substrate for further enzymatic hydrolysis (by breaking down the fiber) to yield further ethanol. The presence of cellulose and hemicellulose could be utilized by appropriate enzymes (i.e., cellulases and hemicellulases) to form glucose, which can be further converted by fermentation into ethanol. In fact, a few studies have begun to examine the potential to convert the fiber portion into ethanol (Mosier et al 2005; Kim et al 2008a,b).

Another observation was the relative high presence of starch in the DDGS. It is true that $100 \%$ of the starch can not be practically converted to ethanol in a typical ethanol plant, and the residual starch will ultimately pass to the coproduct stream. If DDGS is subjected to enzymatic degradation with cellulase and hemicellulases to yield ethanol, then the addition of amylase would also convert the leftover starch to glucose, then to ethanol. The large protein molecules and the presence of unknown inhibitory proteases can possibly inhibit the fermentation process. Deproteinization studies could elucidate further aspects of this problem and could help in reducing the issue of the partial starch conversion.

The presence of glucose, even in small quantities, revealed that the fermentation efficiency of the ethanol plants in this study was not $100 \%$. The ethanol production process consists of multistep enzymatic reactions, where the corn starch is converted to glucose, and then to ethanol by the Embden-Meryerhof-Parnas pathway (Kelsall and Lyons 2003). Key steps include gelatinization $(\alpha-$ amylase breaks the starch to give access to the enzymes), liquefaction (starch is converted to dextrin), saccharification (which yields glucose molecules by glucoamylase), and fermentation by yeast to yield ethanol. The conversion of glucose to ethanol is an anaerobic alcoholic fermentation step (Kelsall and Lyons 2003). The presence of glucose in the DDGS strongly suggests that the ethanol production process was unable to convert all fermentable sugars. Changes in the fermentation temperatures, $\mathrm{pH}$, strains, and enzyme activities are possible reasons why the process was not $100 \%$ efficient.

\section{DDGS NMR Spectroscopy}

Nuclear magnetic resonance (NMR) reveals the nature of the compounds present in biomaterials (Fig. 2). The results of carbon partitioning through NMR spectroscopy is shown in Table III. Averaged over all the samples, the highest C-group was $O$-alkyl with an average $52.81 \%$, followed by alkyl (mean of $28.86 \%$ ), aromatic (mean of $10.75 \%$ ), carboxyl (mean of $7.56 \%$ ), and carbonyl (mean of $0.11 \%$ ). These trends were irrespective of plant and sampling time. To date, no previous studies with NMR spectroscopy have been done for DDGS. These results indicate the nature of the compounds present and possible value-added uses that could be developed from DDGS in the future.

Alkyl $\left(\mathrm{CH}_{3} \mathrm{O}\right)$ groups are results of the deprotonation from the alcohol molecules (Fletcher 1974). A high number of alkyl groups indicate the presence of straight-chain compounds such as simple carbohydrates and possibly alkoxyl groups. However, aromatic compounds were not found in high amounts. Aromatic compounds are made of benzene rings, usually found in secondary plant metabolites like carotenoids, shikimic acids, plant steroids, etc. (Trevor 1975). Thus, a relatively lower percentage of these compounds indicates that it would probably not be efficient to use DDGS for harvesting pharmaceutical compounds such as antioxidants, carotenoids, or other such value-added molecules (which consist of aromatic ring structures). Phytosterols, aromatic nutraceutical compounds, contained in the fiber portion of the DDGS because phytosterols are found in the cell walls and fibrous tissue of corn kernels. Most of these phytosterols were associated with the pericarp layer (Singh et al 2001a). But additional studies showed a low amount of phytosterols recovered in the aspirated (fiber-rich) part of fractionated DDGS (Singh et al 2001b). This indicates that using DDGS as a source of nutraceuticals may be difficult with DDGS due to low concentrations of these aromatic compounds.

Biodiesel is an ester that can be produced from vegetable oils, animal fats, algae, or even recycled greases. It is commonly used as a fuel additive in trucks and other vehicles (USDOE 2008. Available online at: http://www1.eere.energy.gov/biomass). The presence of charged alkoxyl groups and fatty acid levels suggest a probability of utilizing such esters from DDGS (Hassner 2002). Biodiesel production from DDGS is a concept that has begun to garner interest (Haas et al 2007).

The presence of hydrocarbons would favor the gasification of DDGS, which is the conversion of biomass to a gas mixture of hydrogen, methane, and carbon monoxide (USDOE 2008). Furthermore, DDGS itself may prove favorable for more ethanol production using enzymatic hydrolysis of the fibers, due to the higher amounts of carbohydrate compounds that are present. On the other 
hand, higher $O$-alkyl groups with charged electrons on the oxygen molecules may enhance the binding properties of DDGS, and it may be able to be used in biocomposites as biofillers. Several studies have successfully used DDGS in plastic composites (Tatara et al 2007; Cheesbrough et al 2008; Tatara et al 2009).

\section{DDGS Particle Size and Image Analysis}

The results of the image analysis are shown in Table V. There were many differences in the size and shape parameters (i.e., minimum diameter, maximum diameter, area, and roundness) for various size fractions. For each plant, particles were sampled from different screens from no. $8(2.38 \mathrm{~mm})$ to no. $100(149 \mu \mathrm{m})$. Geometric mean diameter, or median size $\left(\mathrm{d}_{\mathrm{gw}}\right)$, was highest in Plant C, followed by Plant A, then Plant B. Standard geometric deviation $\left(S_{\log }\right)$ was greater in Plant $A$, followed by Plant $C$, then Plant B. Particle diameters were $6.87-0.17 \mathrm{~mm}$ for Plant A, and $6.40-0.50 \mathrm{~mm}$ for Plant B, for Plant C they were $29.00-0.36 \mathrm{~mm}$. The highest average area was in particles from Plant $C(16.70$ $\mathrm{mm}^{2}$ ). For the other two plants, the values of average areas were quite similar (5.11 and $\left.5.06 \mathrm{~mm}^{2}\right)$.

Roundness is the degree of abrasion of a grain particle, as shown by the sharpness of its edges and corners. By roundness, we mean either the sphericity of a three-dimensional body, or the circularity of a two-dimensional figure (Cox 1927). The sphericity of a three-dimensional body may be expressed by the degree to which the ratio of its volume to its surface area approaches that of a sphere. For two-dimensional particles, it is measured by the degree to which the ratio of the area to the circumference approaches that of a circle. It is expressed mathematically as $\mathrm{K}=\mathrm{A}$ $\times 4 \pi /(\operatorname{Pr})^{2}$, where $\mathrm{A}$ is the area, $\mathrm{P}$ is the perimeter, $\mathrm{r}$ is the particle radius, and $\mathrm{K}$ is a constant. The $\mathrm{K}$ constant depends on the shape of the particle; $\mathrm{K}=1$ for a circle or sphere, but $<1$ for any other shape. $\mathrm{K}$ represents the percentage ratio $(\%)$ of the particle area to that of a circle with the same perimeter (Cox 1927). For example, if $\mathrm{K}$ is 0.78 of a square, it means that a square contains just $78 \%$ of the area that a circle with the same perimeter would contain. Thus, the higher the roundness value, the more regular and smooth the edges of the object.

The highest roundness values were in Plant A (64.30\%), then Plant C (56.61\%), followed by Plant B (31.30\%). From these findings, we can say that the DDGS from Plant A and Plant C have more round edges than Plant B. A roundness ratio from 96$80 \%$ is called a well rounded object; $95-74 \%$ is called a fairly well rounded object; and 83-60\% is called angular (Cox 1927). Not surprisingly, DDGS particles were irregular, angular particles.

More irregularity on the edges (i.e., roughness) would possibly favor using these particles in composites. The particles from the Plant B have lower roundness ratios and thus have sufficient roughness on the edges. Large particles were from Plant $\mathrm{C}$, which had the highest area and maximum diameter. Large particle sizes favor use in biocomposites but lower roundness values $(56.61 \%)$, would not favor essential lock and key mechanisms required to form composites, thus binders may be necessary for these particles as well.

TABLE IV

Overall Physical and Chemical Properties of DDG

\begin{tabular}{|c|c|c|c|c|}
\hline & Minimum & Maximum & Mean & Standard Deviation \\
\hline \multicolumn{5}{|c|}{ Physical properties ( $n=5$ for each property $)^{\mathrm{a}}$} \\
\hline Moisture (\% db) & 2.17 & 2.71 & 2.57 & 0.26 \\
\hline Water activity & 0.42 & 0.42 & 0.42 & 0.00 \\
\hline Angle of repose $\left(^{\circ}\right)$ & 20.32 & 29.9 & 23.88 & 3.73 \\
\hline Energy content $(\mathrm{MJ} / \mathrm{kg}, \mathrm{db})$ & 21.55 & 21.57 & 21.56 & 0.01 \\
\hline Thermal conductivity $\left(\mathrm{W} / \mathrm{m}{ }^{\circ} \mathrm{C}\right)$ & 0.06 & 0.08 & 0.07 & 0.01 \\
\hline Thermal diffusivity $\left(\mathrm{mm}^{2} / \mathrm{sec}\right)$ & 0.14 & 0.17 & 0.15 & 0.02 \\
\hline Color $b$ & 23.76 & 24.29 & 24.07 & 0.20 \\
\hline \multicolumn{5}{|c|}{ Chemical properties ( $n=5$ for each property $)^{\mathrm{a}}$} \\
\hline Crude ash $(\% \mathrm{db})$ & 8.84 & 11.43 & 10.91 & 1.53 \\
\hline $\operatorname{NDF}(\% \mathrm{db})$ & 29.39 & 33.82 & 31.43 & 0.64 \\
\hline $\mathrm{ADF}(\% \mathrm{db})$ & 27.99 & 29.42 & 28.69 & 1.63 \\
\hline Crude fiber $(\% \mathrm{db})$ & 10.49 & 14.95 & 12.33 & 2.08 \\
\hline Crude protein $(\% \mathrm{db})^{\mathrm{b}}$ & 30.6 & 31.2 & 30.9 & 0.42 \\
\hline
\end{tabular}

Carbon partitioning $(\%)(n=1 \text { for each property })^{\mathrm{c}}$

\begin{tabular}{ccccc} 
Alkyl $(0-50 \mathrm{ppm})$ & $O$-Alkyl $(50-100 \mathrm{ppm})$ & Aromatic $(100-160 \mathrm{ppm})$ & Carboxyl $(160-190 \mathrm{ppm})$ & Carbonyl (190-220 ppm) \\
27.46 & 50.08 & 15.15 & 7.11 & 0.18 \\
\hline
\end{tabular}

${ }^{a}$ Each property ( $n=5$ sample), based on 5 replicates analyzed from 1 plant collected in 1 batch.

${ }^{\mathrm{b}}$ Each property ( $n=2$ sample), based on 2 replicates analyzed from 1 plant collected in 1 batch.

${ }^{\mathrm{c}}$ Each property ( $n=1$ sample), based on 1 replicate analyzed from 1 plant collected in 1 batch.

TABLE V

Size and Shape Results for DDGS Particles ${ }^{\mathrm{a}}$

\begin{tabular}{|c|c|c|c|c|c|c|}
\hline Plant & $\mathrm{D}_{\mathrm{gw}}(\mathrm{mm})^{\mathrm{b}}$ & $\mathrm{S}_{\mathrm{gw}}(\mathrm{mm})^{\mathrm{b}}$ & $D_{\max }(\mathbf{m m})^{\mathrm{c}}$ & $\mathrm{D}_{\min }(\mathbf{m m})^{\mathrm{c}}$ & Area $\left(\mathrm{mm}^{2}\right)^{\mathbf{c}}$ & Roundness $(\%)^{\mathrm{c}}$ \\
\hline $\bar{A}$ & $0.85 b$ & $0.51 \mathrm{a}$ & $6.87 b$ & $0.17 \mathrm{a}$ & $5.11 \mathrm{~b}$ & $64.30 \mathrm{a}$ \\
\hline B & $0.69 \mathrm{c}$ & $0.37 \mathrm{c}$ & $6.40 \mathrm{~b}$ & $0.50 \mathrm{a}$ & $5.66 \mathrm{~b}$ & $31.30 \mathrm{c}$ \\
\hline $\mathrm{C}$ & $1.19 \mathrm{a}$ & $0.47 b$ & $29.00 \mathrm{a}$ & $0.36 \mathrm{~b}$ & $16.70 \mathrm{a}$ & $56.61 \mathrm{~b}$ \\
\hline
\end{tabular}


$(\mathrm{mm})$. Values followed by the same letter are not significantly different $(P<0.05)$.

${ }^{\mathrm{b}}$ Each property ( $n=6$ sample) from each plant, based on 2 batches collected from each plant, 3 replicates analyzed per batch.

c Each property ( $n=4$ sample) from each plant, based on 2 batches collected from each plant, 2 replicates analyzed per batch. 
Flowability of powders depends on interparticle friction, which is dominated by particle shape, size, and surface roughness. As the surface roughness increases, the interparticle friction increases and lessens efficient flow.

For all particle sizes examined, image analysis and particle size determination revealed that there were fewer differences among the DDGS particles between the batches and more differences for particles collected from different plants. Grain size and particle shape depend very much on the processing machines used by the plants, and these differ from one plant to another but not between batches within a particular plant.

\section{DDG Physical Properties}

Physical properties of DDG are shown in Table IV. Moisture content of DDG was $2.17-2.71 \% \mathrm{db}$. This was much less than the moisture content of DDGS, which was $3.54-8.21 \%$. It was also less than the level of moisture content required for safe storage, which is $\approx 12 \%$. With increases in moisture content, there have been problems in the flowability of DDGS (Ganesan et al 2008b). Our results indicate that DDG should be suitable for long-time storage and should have sound flowability and handling characteristics. The $A_{\mathrm{w}}$ was very low at 0.42 . This value was less than that of DDGS (0.48). Low $A_{\mathrm{w}}$ will prevent microbial spoilage and should facilitate long-term storage and handling (Rosentrater 2006). The bulk density was $467.30-482.24 \mathrm{~kg} / \mathrm{m}^{3}$. Bulk density of the DDG was less than that of DDGS (467.7-509.83 kg/m 3 ). DDGS does have additional soluble material, but DDG does not, which could explain why the density of DDGS is higher than the DDG (Ganesan et al 2008b).

The angle of repose was $20.3-29.9^{\circ}$. The maximum value was lower in DDG than DDGS, and therefore DDG is potentially more free-flowing than DDGS. This may be possible because DDG does not have the additional soluble fat layers on the surface of the particles, which would affect the frictional characteristics of the particles and thus the angle of repose.

The energy content of DDG was slightly higher than DDGS, with an average of $21 \mathrm{MJ} / \mathrm{kg}$. Normally, due to relatively high fat content in DDGS, the energy content should be higher than DDG. Because DDG was only from one plant (and one batch), there could be a possibility of insufficient sampling. Also, the slightly higher protein content in DDG (mean value of $30.9 \% \mathrm{db}$ ) could be another possible reason for the higher energy content.

Thermal conductivity was $0.06-0.08 \mathrm{~W} / \mathrm{m} \cdot{ }^{\circ} \mathrm{C}$ and diffusivity was within $0.14-0.17 \mathrm{~mm}^{2} / \mathrm{sec}$. These ranges of thermal proper- ties for DDG were very near those obtained for DDGS, but the variation observed was much less for the thermal properties of the DDG.

Hunter $L$ value was 52.43-54.82; Hunter $a$ value was 5.9-6.72; Hunter $b$ was from 23.76-24.29. The values of the color scales differed substantially from those for the DDGS. This is a result of different processing conditions and different nutritional characteristics than DDGS, and is due to the absence of CDS (Goihl 1993; Ergul et al 2003).

\section{DDG Chemical Properties}

Chemical properties of DDG are shown in Table IV. The greatest constituent was NDF (average value $31.43 \% \mathrm{db}$ ), then crude protein (average value $30.9 \% \mathrm{db}$ ), followed by $\mathrm{ADF}$ (average value $28.69 \% \mathrm{db}$ ), crude fiber (average value $12.33 \% \mathrm{db}$ ), total starch (average value of $11.01 \% \mathrm{db}$ ), crude ash (average value $10.91 \%$ $\mathrm{db}$ ), crude fat (average value $8.9 \% \mathrm{db}$ ), then glucose (mean value of $0.21 \% \mathrm{db})$.

The NDF content was $29.39-33.82 \% \mathrm{db}$. Thus, the NDF levels were very close to those in DDGS. However, the average NDF value of DDG $(31.43 \% \mathrm{db})$ was a little lower than the average NDF content of DDGS $(36.74 \% \mathrm{db})$. ADF value was 27.99$29.42 \% \mathrm{db}$. Thus, the ADF content in DDG was almost double that of DDGS. Because NDF is the sum of ADF and hemicellulose, the higher ADF value indicates a lower amount of hemicellulose in DDG compared to that in DDGS because the NDF values were very similar. Thus, DDG had higher cellulose and lignin values. So degradation with only hemicellulase enzymes may not yield sufficient glucose molecules if DDG is subjected to a single enzymatic degradation for future value-added uses (such as conversion to additional ethanol).

Crude protein of DDG was $30.6-31.2 \% \mathrm{db}$. It was slightly higher than in DDGS because the DDGS is formed by incorporation of CDS, which is high in fat compounds.

The fat content of DDG was $8.1-9.7 \% \mathrm{db}$. These result paralleled the findings of Ganesan et al (2008b). As suspected, the fat content was lower in DDG than in DDGS because there was no added CDS. The total starch content of the DDGS was 9.19$12.83 \% \mathrm{db}$. This range was quite close to that of DDGS but the maximum value was higher in DDGS $(14.04 \% \mathrm{db})$. Again, due to similar processing techniques, DDG and DDGS had similar starch levels. However, the presence of very little glucose in the DDG would be due to reasons similar to that for DDGS: both coproducts came from a similar fermentation process.

TABLE VI

Overall Physical and Chemical Properties of DWG



${ }^{\text {a }}$ Each property ( $n=30$ sample), based on 5 replicates analyzed from 3 plants collected in 2 batches.

${ }^{\mathrm{b}}$ Each property ( $n=12$ sample), based on 2 replicates analyzed from 3 plants collected in 2 batches. 


\section{DDG NMR Spectroscopy}

Carbon partitioning of DDG (Table IV) was quite similar to the DDGS results. The highest ratio was in the $O$-alkyl group $(50.08 \%)$, followed by alkyl (27.46\%), aromatic (15.15\%), carboxyl (7.11\%), and carbonyl $(0.18 \%)$. DDG could also be used for biocomposites or enzymatic hydrolysis due to high carbohydrates and charged alky groups. The aromatic group was a bit higher in DDG than DDGS. However, new studies should examine DDG from multiple plants over time to fully examine these functional groups.

\section{DWG Physical Properties}

Values of physical properties of DWG are given in Table VI. The moisture content of DWG was $22.85-43.66 \% \mathrm{db}$ and was very much higher than DDGS, which was expected because DWG is the wet form of DDG. There were differences in moisture content among the plants as well between the batches. Higher moisture content in DWG creates problem in transportation, storage, and shipping. The $A_{\mathrm{w}}$ was $\approx 0.96(0.93-0.99)$. High $A_{\mathrm{w}}$ facilitates rapid microbial spoilage. The $A_{\mathrm{w}}$ values $>0.9$ foster mold, bacterial, and other fungal growth in biomaterials. Thus, long-term storage and long-distance transportation is not favorable.

Bulk density of DWG was $794.56-1107.6 \mathrm{~kg} / \mathrm{m}^{3}$. Bulk density was greater for DWG than for DDGS, which was due to the greater quantity of water molecules in DWG. DWG had greater thermal conductivity (average value $0.12 \mathrm{~W} / \mathrm{m} \cdot{ }^{\circ} \mathrm{C}$ ) and thermal diffusivity (average value $0.11 \mathrm{~mm}^{2} / \mathrm{sec}$ ) than DDGS. This was also due to higher water levels in the DWG. Thus, unlike DDGS, DWG may be challenging for further chemical processing or other value-added uses because it shows higher conductivity, $A_{\mathrm{w}}$, and bulk density. Mean $L, a, b$ values were $50.94,6.91$, and 23.75 , respectively, and thus DWG was slightly brighter than DDGS because the DDGS has been subjected to drying operations.

\section{DWG Chemical Properties}

Chemical property results for DWG are provided in Table VI. There was a fairly high fiber content in the DWG samples. The greatest constituent was NDF (mean value $33.80 \% \mathrm{db}$ ), followed by crude protein (mean value $28.62 \% \mathrm{db}$ ), ADF (mean value $14.22 \%$ $\mathrm{db}$ ), crude ash (mean value $13.31 \% \mathrm{db}$ ), crude fiber (mean value $12.04 \% \mathrm{db}$ ), total starch (mean value $11.24 \% \mathrm{db}$ ), crude fat (mean value $11.12 \% \mathrm{db}$ ), and glucose (mean value $0.66 \% \mathrm{db}$ ). DWG showed very similar amounts of fiber and protein as DDGS. The total starch content of DWG was quite similar to DDGS as well.

\section{CONCLUSIONS}

The main objective of this study was to examine various physical and chemical properties of DDGS, DDG, and DWG, including image analysis and NMR spectroscopy. The main idea was to provide an overall picture of these coproducts which will affect end-use options. Chemical data are essential for livestock diet formulations but they are also important for pursuing other potential uses such as human foods, bioenergy, biocomposites, or even for harvesting of important nutraceutical molecules, to name a few. Physical property information, on the other hand, is critical for the design and operation of processing equipment (such as dryers, conveyors, mixers, pellet mills, extruders, etc.), processing facilities, and storage structures (such as flat storage buildings and vertical silos). LSD testing showed differences in the properties among three plants, which was not surprising. This study highlights the necessity for simultaneous optimization between various physical and chemical properties, and the need for consistency of the coproducts among plants and between batches in a given plant.

\section{ACKNOWLEDGMENTS}

We would like extend gratitude to the ethanol plants that contributed coproduct samples, Agricultural Experiment Station at South Dakota State University and USDA-ARS for providing equipment and financial support, and we would like to thank Michael Heldrith, Department of Microbiology, South Dakota State University, for laboratory assistance with particle imaging.

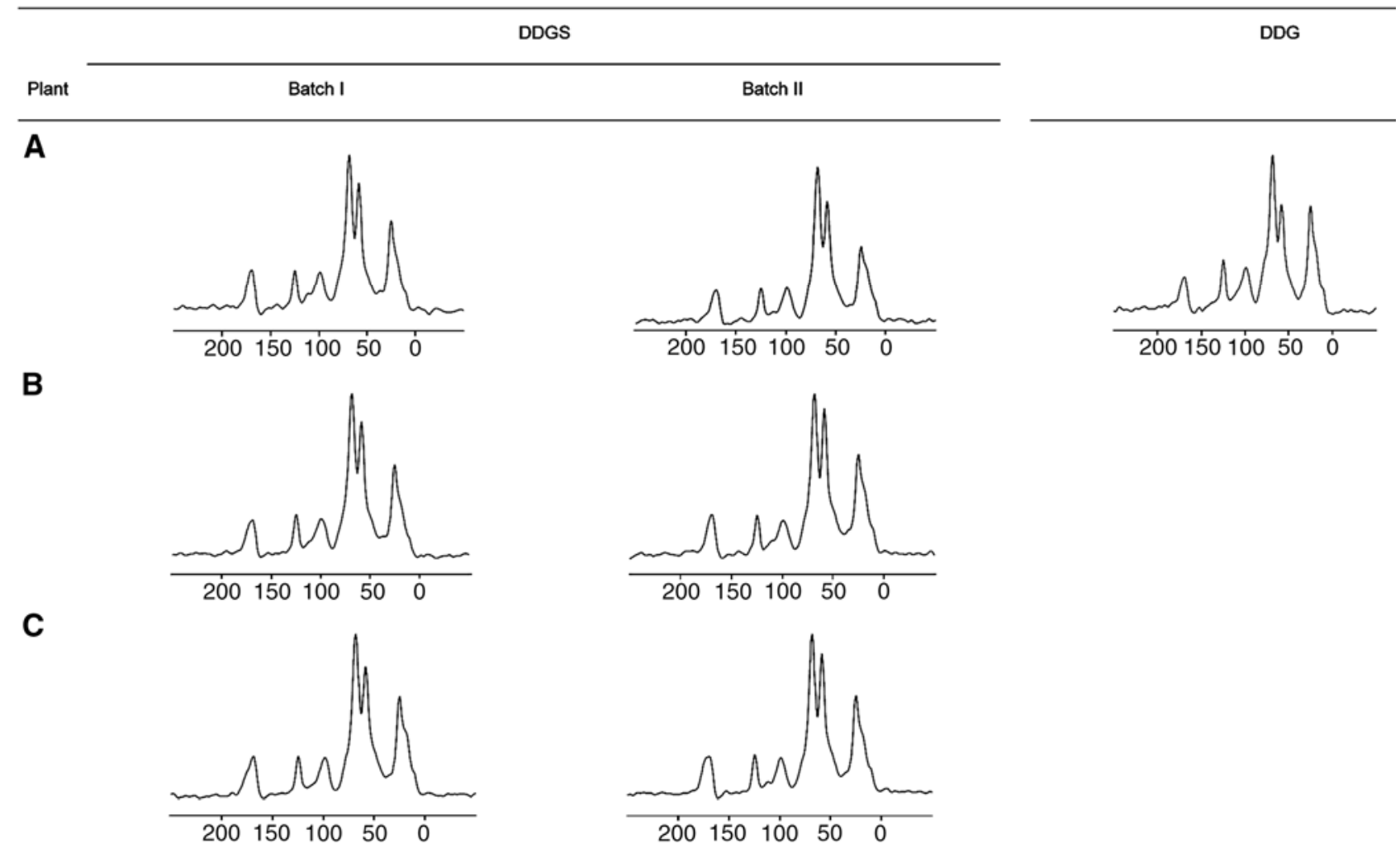

Fig. 2. NMR spectra for DDGS and DDG ( $n=1$ for each batch from each plant); $x$-axis ppm units. Carbon partitions of alkyl (0-50 ppm), $O$-alkyl (50$100 \mathrm{ppm})$, aromatic (100-160 ppm), carboxyl (160-190 ppm), and carbonyl (190-220 ppm). 


\section{LITERATURE CITED}

AACC International. 2010. Approved Methods of Analysis, 11th Ed. Methods 08-01 and 44-19. Available online only. AACC International: St. Paul, MN.

AOAC. 2000. Official Methods of Analysis of the Association of Analytical Chemists. 990.03 and 920.39. The Association: Gaithersburg, MD.

ASAE. 2004. Standards, Engineering Practices, Data, 51st Ed. S19.3. The Society: St Joseph, MI.

Baghe-Khandan, M., Choi, S. Y., and Okos, M. R. 1981. Improved line heat source thermal conductivity probe. J. Food Sci. 46:1430-1432.

Bals, B., Dale, B., and Balan, V. 2006. Enzymatic hydrolysis of distillers dry grain and solubles (DDGS) using ammonia fiber expansion pretreatment. Energy Fuels 20:2732-2736.

Barbosa-Canovas, G. V., and Vega-Mercado, H. 1996. Dehydration of Foods. International Thomson Publishing: New York.

Belyea, R. L., Rausch, K. D., and Tumbleson, M. E. 2004. Composition of corn and distillers dried grain with solubles from dry grind ethanol processing. Bioresource Technol. 94:293-298.

Buchheit, J. K. 2002. Distillers dried grains with solubles. Report No.11. I-FARM. Online at http://www.siu.edu/ readi/grains/factsheets/historyof ethanolproduction.pdf. Southern Illinois University: Carbondale, IL.

Cheesbrough, V., Rosentrater, K. A., and Visser, J. 2008. Properties of distillers grains composites: A preliminary investigation. J. Polym. Environ. 16:40-50.

Chevanan, N., Muthukumarappan, K., and Rosentrater, K. 2007. Extrusion studies of aquaculture feed using distillers dried grains with solubles and whey. Food Bioprocess Technol. 2:177-185.

Chevanan, N., Rosentrater, K., and Muthukumarappan, K. 2008. Effects of DDGS, moisture contents, and screw speed on the physical properties of extrudates in single screw extrusion. Cereal Chem. 85:132-139.

Cox, E. P. 1927. Roundness of sand grain. J. Paleontology 1:179.

Ergul, T., Martinez Amerzcua, C., Parsons, C. M., Walters, B., Brannon, J., and Noll, S. L. 2003. Amino digestibility in corn distillers dried grain with solubles. Poultry Sci. 82 (S1):70.

Fisher, R. A. 1948. The Design of Experiments. Oliver and Boyd: Edinburgh.

Fletcher, J. H. 1974. Nomenclature of Organic Compounds: Principles and Practice. ACS: Washington, DC.

Ganesan, V., Rosentrater, K. A., and Muthukumarappan, K. 2007. Sorption isotherm characteristics of distillers dried grain with solubles (DDGS). Trans. ASABE 51:169-176.

Ganesan, V., Rosentrater, K. A., and Muthukumarappan, K. 2008a. Effect of moisture content and soluble levels on the physical and chemical properties of DDGS. Cereal Chem. 85:464-470.

Ganesan, V., Muthukumarappan, K., and Rosentrater, K. 2008b. Effect of flow agent addition on physical properties of DDG with varying moisture content and soluble percentages. Trans. ASABE 51:591-601.

Goihl, J. 1993. Color, odor good indicators of DDGS nutritional value. Feedstuffs 65(21):1.

Haas, M. J., Scott, K. M., Foglia, T. A., and Marmer, W. N. 2007. The general applicability of in situ transesterification for the production of fatty acid esters from a variety of feedstocks. J. AOCS 84:963-970.

Hassner, A. 2002. Organic Syntheses Based on Name Reaction, 2nd Ed. Pergamon Publishers: Amsterdam.

Jaques, K. A., Lyons, T. P., and Kelsall, D. R. 2003. Alcohol Textbook. University Press: Nottingham, UK.

Johnson, L. A., and May, J. B. 2003. Wet milling: The basis for corn biorefineries. Pages 449-494 in: Corn Chemistry and Technology, 2nd Ed. P. J. White and L. A. Johnson, eds. AACC International: St. Paul, MN.

Kelsall, D. R., and Lyons, T. P. 2003. Grain dry milling and cooking pro- cedures: Extracting sugars in preparation for fermentation. In: Alcohol Textbook. K. A. Jaques, T. P. Lyons, and D. R. Kelsall, eds. University Press: Nottingham, UK.

Kim, Y., Mosier, N. S., and Ladisch, M. R. 2008a. Process simulation of modified dry grind ethanol plant with recycle of pretreated and enzymatically hydrolyzed distillers' grains. Bioresource Technol. 99:51775192.

Kim, Y., Hendrickson, R., Mosier, N. S., Ladisch, M. R., Bals, B., Balan, V., and Dale, B. 2008b. Enzyme hydrolysis and ethanol fermentation of liquid hot water and AFEX pretreated distillers' grains at high-solids loadings. Bioresource Technol. 99:5206-5215.

Knudsen, B. K. E. 1997. Carbohydrate and lignin contents of plant materials used in animal feeding. Animal Feed Sci. Technol. 67:319-338.

Mohsenin, N. N. 1980. Physical properties of plant and animal materials. Vol. I. Structure, Physical Characteristics, and Mechanical Properties. Gordon and Breach Science: New York.

Mosier, N. S., Hendrickson, R., Brewer, M., Ho, N., Sedlak, M., Dreshel, R., Welch, G., Dien, B. S., Aden, A., and Ladisch, M. R. 2005. Industrial scale-up of $\mathrm{pH}$-controlled liquid hot water pretreatment of corn fiber for fuel ethanol production. Appl. Biochem. Biotechnol. 125:77-97.

Popov, I. K., Krstic, S. B., Obradonic, M. C., Pavlovic, M. C., Pavlovic, L. J., and Ivanovic, E. R. 2003. The effect of the particle shape and structure on the flowability of the electrolytic copper powder. I. Modeling of representative powder particle. J. Serbian Chem. Soc. 68:771777.

RFA. 2009. Ethanol facts: Agriculture, feeding the world, fueling the nation. Available at online at: http://www.ethanolrfa.org. The Association: Washington, DC.

Rosentrater, K. A. 2006. Physical properties of distillers dried grain with solubles (DDGS). Appl. Eng. Agric. 22:589-595.

Rosentrater, K. A. 2007. Ethanol processing coproducts: A review of some current constraints and potential directions. Int. Sugar J. 109:1-12.

Rosentrater, K. A., and Muthukumarappan, K. 2006. Corn ethanol coproducts: Generation, properties, and future prospects. Int. Sugar J. 108: 648-657.

Singh, V., Moreau, R. A., and Cooke, P. H. 2001a. Effect of corn milling practices on the fate of aluerone layer cells and their unique phytosterols. Cereal Chem. 78:436-441.

Singh, V., Moreau, R. A., Hicks, K. B., Belyea, R. L., and Staff, C. H. 2001b. Removal of fiber from distillers dried grain with solubles (DDGS) to increase value. Trans ASAE 45:389-392.

Speihs, M. J., Whitney, M. H., and Shurson, G. C. 2002. Nutrient database for distiller's dried grains with solubles produced from new ethanol plants in Minnesota and South Dakota. J. Animal Sci. 80:26392645.

Tatara, R. A., Suraparaju, S., and Rosentrater, K. A. 2007. Compression molding of phenolic resin/corn-based DDGS blends. J. Polym. Environ. 15:89-95.

Tatara, R. A., Rosentrater, K. A., and Suraparaju, S. 2009. Design properties for molded, corn-based DDGS-filled phenolic resin composites. Industrial Crops and Products 29: 9-15.

Trevor, R. 1975. Organic Constituents of Higher Plants: Their Chemistry and Inter Relationships. Cordess Press: North Amherst, MA.

USDA. 1999. Practical procedures for grain handlers: Inspecting grain. Available online at http://151.121.117/pubs/primer.pdf. GIPSA: Washington, DC.

Weigel, J. C., Loy, D., and Kilmer, L. 1997. Feed Co-Products of the Dry Corn Milling Process. RFA: Washington, DC.

Xiong, Y., Bartle, J. L., and Preston, R. L. 1990. Improved enzymatic method to measure processing effects and starch availability in sorghum grain. J. Anim. Sci. 63:3861.

[Received February 2, 2010. Accepted April 1, 2010.] 